\title{
Evaluation of Cassava Peel - Cassava Leaf Meal Based Diets for Milk Production by the West African Dwarf Goats in South Eastern Nigeria.
}

\author{
A. I. Ukanwoko ${ }^{2}$ And J. A. Ibeawuchi ${ }^{1}$. \\ ${ }^{1}$ Department of Animal Production and Livestock Management College of Animal Science and Animal \\ Production. Michael Okpara University of Agriculture, Umudike, Abia State, Nigeria. \\ ${ }^{2}$ Department of Animal Science and Fisheries, University of Port Harcourt. P. M. B. 5323 Choba, Port \\ Harcourt, Rivers State, Nigeria.
}

\begin{abstract}
An experiment was conducted to determine the effects of cassava peel - cassava leaf meal based diets on the milk yield and composition of WAD goats. Four lactating WAD does were housed individually in pens and were assigned to the experimental diets in a $4 \times 4$ Latin Square Design Experiment and fed for 56days. Drinking water was offered liberally. Milk yield (MY) was measured and analyzed weekly for total solids (TS), butterfat (BF), crude protein $(C P)$, solids- not- fat ( $S N F)$, lactose, ash and milk energy. $M Y, B F, C P, S N F$, ash, milk energy, solids - corrected- milk yield (SCM) and fat - corrected- milk yield (FCM) did not differ significantly $(P>0.05)$ among the treatment groups. Total solids and lactose were significantly $(P<0.05)$ different among treatment groups. The group on diet B (10\% cassava leaf meal (CLM)) recorded the highest total solids percentage (12.81\%) while the group on diet D (30\% CLM) recorded the lowest. The group on diet $B$ also recorded the highest lactose content (4.30) while the least was recorded for the group on diet D (4.18). The relationship between $M Y$ and various milk constituents indicated negative correlation between $M Y$ and TS, $M Y$ and $B F, M Y$ and $S N F, M Y$ and lactose. However, these correlations were not significant $(P>0.05)$. Positive correlation existed between $B F$ and TS, milk protein and TS, milk energy and TS, lactose and SNF, milk energy and $B F, B F$ and milk protein. Milk protein and $B F$ were highly significant $(P<0.001)$ and positively correlated. Milk protein and SNF were negative and significantly correlation while a significant positive correlation existed between BF and milk protein. Diet D (30\% CLM) which gave the highest MY, the lowest total solids and lactose percentage is recommended.
\end{abstract}

Keywords: Cassava leaf meal, lactose, milk yield, total solids, WAD goats.

\section{Introduction}

In Nigeria, the indigenous cattle have been the major source of domestic meat and milk supply (Zahradden et al., 2007). Milk supply from other animals such as sheep, goats and camels is negligible (Ibeawuchi and Dalyop, 1995). The domesticated goat (Capra hircus) is now found throughout the continent in many forms including Nigeria with a population of 29.2million (FAO, 2005). In Nigeria the rearing of goats is mainly traditional and as a result, it is characterized by inadequate feeding. This has necessitated the search for non - conventional feedstuffs which are cheap and not in high demand by humans (Amaefule, 2002). Goats in the country are kept mainly for meat production, their milk is rarely used for human consumption (Butswat et al., 2002). Meat is the major form in which goats are consumed in Nigeria (Alikwe et al., 2011), however, there is a growing awareness of the importance of goats as a source of milk for man (Malau - Aduli et al., 2001). Goat milk is more widely produced than sheep milk and globally goat production yields 60 per cent of its value as milk, 35 per cent as meat and 5 per cent as skin (Malau - Aduli et al., 2001).

Cassava leaf has high protein content $(16.7-39.90 \%)$ (Yousuf et al., 2007) with almost $85 \%$ of the crude protein as true protein (Ravindran, 1991). This is due to the presence of tannins which form tannin protein complex that by - pass the rumen (Wanapat et al., 1997). Cassava peels can be processed in order to reduce cyanogenic glycosides and phytate content and to preserve their nutritive quality (Oboh, 2006; Salami et al., 2003). This can either be by sun drying, ensiling and soaking + sun drying (Salami et al., 2003).

This study was therefore aimed at evaluating cassava peel - cassava leaf meal diets for milk production by the West African Dwarf goats in South Eastern Nigeria.

\section{Environment of study}

\section{Materials and Methods}

This study was conducted at the Teaching and Research Farm of Michael Okpara University of Agriculture, Umudike located in Abia state on latitude $05^{\circ} 29^{\circ}$ north, longitude $33^{\circ}$ east at altitude of 122 meters or 400 feet above sea level. It falls within the humid rain forest zone of West Africa, which is characterized by 
long duration of rainfall (April-October) and short period of dry season (November-March). Average rainfall is $2169.8 \mathrm{~mm}$ in $148-155$ rain days. Average temperature is $26^{\circ} \mathrm{C}$ with maximum of $32{ }^{\circ} \mathrm{C}$ and minimum of $22{ }^{\circ} \mathrm{C}$. Relative humidity ranges from $50-95 \%$.

The cassava peels used for this trial were collected after harvesting the cassava tubers from the processing unit of the National Root Crops Research Institute, Umudike. The fresh cassava peels were sundried on a concrete floor for 3 - 5days depending on the intensity of the sun. The sundried cassava peels were then milled and bagged in sacks. The cassava leaves were collected from the cassava plantation of the National Root Crops Research Institute, Umudike. The cassava leaves were sundried on a concrete floor for 3days. The dried leaves were crushed and bagged in sacks for feed formulation. Palm kernel cake, brewers' dry grain, soybean meal, bone meal and common salt were purchased and used for the feed formulation. The diets were designated $\mathrm{A}, \mathrm{B}, \mathrm{C}$ and $\mathrm{D}$ as shown in Table 1 below.

Table 1. Composition of Experimental diets.

\begin{tabular}{|c|c|c|c|c|}
\hline \multicolumn{5}{|c|}{ Diets } \\
\hline Ingredients (\%) & A & $\mathrm{B}$ & $\mathrm{C}$ & \\
\hline Cassava peel & 62 & 57 & 52 & 47 \\
\hline Cassava leaf meal & 0 & 10 & 20 & 30 \\
\hline Palm kernel cake & 19 & 16 & 12 & 8 \\
\hline Brewers' dried grain & 10 & 8 & 7 & 6 \\
\hline Soya bean meal & 5 & 5 & 5 & 5 \\
\hline Bone meal & 3 & 3 & 3 & 3 \\
\hline \multirow[t]{2}{*}{ Common salt } & 1 & 1 & 1 & 1 \\
\hline & 100 & 100 & 100 & 100 \\
\hline
\end{tabular}

\section{Lactation Studies}

Four lactating West African Dwarf does of 2 -4 years of age and weighing between 14 and $17 \mathrm{~kg}$ were used. Each animal was randomly assigned to one of the four experimental diets in a 4x4 Latin Square Design. The animals were fed individually in separate pens. A period of 7days was allowed for the animals to adjust to the diets and then were weighed weekly for a period of 8 weeks. The experiment lasted for 56days.

\section{Kid Management}

Prior to each day's milking, kids were separated from their dams at $1800 \mathrm{hr}$ on the previous evening following the day of milking. Within this period, kids were fed artificial milk with the aid of a feeding bottle. The kids were allowed access to their dams after they were milked the following day.

\section{Statistical analysis}

The data on milk yield and composition were analyzed using the analysis of variance (ANOVA) procedures appropriate for a Latin Square Design (Steel and Torrie, 1980). Where ANOVA detected significant treatment effects, means were separated using Duncan's Multiple Range Test (Duncan, 1955). Correlation coefficients were computed and simple linear regression used to ascertain the degree of relationship between various parameters of milk.

\section{Results and Discussion}

The proximate constituents of the experimental diets, the cassava peels and the cassava leaf meals used in this study are presented in Table 2.

Table 2. The proximate constituents of the experimental diets, cassava peels and cassava leaf Meal.

\begin{tabular}{lllllll}
\hline Constituents (\%) & Diets & A & C & D & CP & CLM \\
\hline Dry matter & 87.52 & 87.52 & 89.62 & 89.64 & 87.60 & 93.00 \\
Crude protein & 12.56 & 13.00 & 13.00 & 13.52 & 4.90 & 25.10 \\
Crude fiber & 19.35 & 18.65 & 18.60 & 16.15 & 16.60 & 7.90 \\
Ether extract & 1.05 & 1.30 & 1.46 & 2.20 & 2.10 & 5.50 \\
N-free extract & 43.77 & 43.00 & 42.87 & 43.62 & 71.00 & 51.90 \\
Ash & 12.30 & 12.60 & 13.70 & 14.15 & 8.50 & 6.10 \\
*ME (MJ/kgDM) & 1.48 & 1.47 & 1.44 & 1.44 & 1.82 & 1.80 \\
\hline
\end{tabular}

*Calculated, CP = Cassava peel; CLM = Cassava leaf meal

The proximate values for the cassava peel fell within the range reported by Ukanwoko and Ibeawuchi (2012). The proximate constituents of the cassava leaf meal were within the range of values obtained by Ravindran (1991). The dry matter percent was similar for diets A and B and tended to increase as the levels of inclusion of cassava leaf meal increased from diets A to D. The crude protein content was highest in diet D followed by $\mathrm{C}$ and $\mathrm{A}$ with the lowest in diet $\mathrm{B}$. The crude fiber contents were declining with increase in cassava 
leaf meal levels. The ether extract, ash and energy values increased from diets A to D while the nitrogen - free extract values did not show any consistent trend among the diets.

The effect of the experimental diets on milk yield and composition of WAD goats is shown on Table 3 . Milk yield $(\mathrm{g} / \mathrm{d})$ did not differ $(\mathrm{P}>0.05)$ among treatment groups. However, numerically animals fed diet $\mathrm{D}$ had the highest milk yield $(134.99 \mathrm{~g} / \mathrm{d})$ followed by animals on diet $\mathrm{C}(133.07 \mathrm{~g} / \mathrm{d})$, diet $\mathrm{A}(121.21 \mathrm{~g} / \mathrm{d})$ and diet B $(119.73 \mathrm{~g} / \mathrm{d})$. The milk yield in this study falls within the range of $119.73-134.99 \mathrm{~g} / \mathrm{d}$ as against the range of $139.70-233.00 \mathrm{~g} / \mathrm{d}$ reported by Ahamefule (2005). The non - concurrent values might be due to differences in diets fed. Parity and litter size have been identified as strong factors influencing milk yield and composition in lactating animals (Akpa et al., 2001). There were significant differences $(\mathrm{P}<0.05)$ in the total solids values among the treatment groups. Diet B had the highest TS values $(12.81 \%)$ while diet D had the least $(12.35 \%)$. The total solids values in this study fell within a range of $12.35-12.81 \%$. This range fell within the range of $12.45-14.36 \%$ reported by Ibeawuchi and Umoh (1990), lower than the value of $13.16 \%$ reported by Ahamefule et al (2012) and higher than the TS value of $11.63+0.12$ reported by Zahradden et al (2007). There were no significant differences $(\mathrm{P}>0.05)$ in the butterfat contents of the milk of goats that fed the different diets. The range of butterfat values in this study $(4.77-4.92 \%)$ is higher than a butterfat value of $4.74+0.03$ reported by Zahradden et al (2007). Butterfat percentage was highest in milk of goats fed diet B (4.92\%) which had the least milk yield $(119.72 \mathrm{~g} / \mathrm{d})$. The goats on diet $\mathrm{D}$ had the least butterfat values $(4.77 \%)$ but the highest milk yield $(134.99 \mathrm{~g} / \mathrm{d})$. This result agrees with Ibeawuchi (1987) who reported that there is an inverse relationship existing between milk yield and butterfat content of milk. This had been confirmed by Ahamefule et al 2003. There were significant differences $(\mathrm{P}<0.05)$ in the lactose contents of milk produced by goats on the diets. The lactose contents in this study were close to the value of $4.29+0.004 \%$ reported by Zahradden et al 2007.

Table 3. The effects of diets on milk yield and composition of WAD goats fed cassava peel - cassava leaf meal diets.

\begin{tabular}{|c|c|c|c|c|c|c|}
\hline \multirow[b]{2}{*}{ Parameters } & \multicolumn{3}{|c|}{ Diets } & \multirow[b]{2}{*}{ SEM } & & \\
\hline & A & B & $\mathrm{C}$ & & & \\
\hline Milk yield $(\mathrm{g} / \mathrm{d})$ & & 121.21 & 119.17 & 133.07 & 134.99 & 8.69 \\
\hline Total solids $(\%)$ & & $12.54^{\mathrm{b}}$ & $12.81^{\mathrm{a}}$ & $12.74^{\mathrm{a}}$ & $12.35^{\mathrm{c}}$ & 0.14 \\
\hline Milk protein $(\mathrm{Nx} 6.38 \%)$ & & 3.55 & 3.60 & 3.39 & 3.68 & 0.08 \\
\hline $\operatorname{Ash}(\%)$ & & 0.72 & 0.77 & 0.79 & 0.79 & 0.00 \\
\hline $\operatorname{SNF}(\%)$ & & 7.61 & 7.99 & 7.97 & 7.47 & 0.29 \\
\hline Milk Energy(MJ/kg) & & 1.82 & 1.79 & 1.77 & 1.79 & 0.00 \\
\hline $\operatorname{SCM}(\mathrm{kg})$ & & 0.092 & 0.100 & 0.100 & 0.097 & 0.00 \\
\hline $\mathrm{FCM}(\mathrm{kg})$ & & 0.12 & 0.12 & 0.13 & 0.13 & 0.00 \\
\hline
\end{tabular}

${ }^{a b}$ Means on the same row with different superscripts differ significantly $(\mathrm{P}<0.05)$.

$\mathrm{SEM}=$ Standard error of mean, $\mathrm{SNF}=$ Solids - not - fat

$\mathrm{SCM}=$ Solids - Corrected Milk yield, FCM = Fat- Corrected milk yield

The relationship between milk yield and constituents of goat milk are summarized in Table 4 .

Very high positive and significant $(\mathrm{P}<0.001)$ correlation existed between milk energy and $\mathrm{BF}(\mathrm{r}=0.999)$. This agrees with Ahamefule et al (2004) who reported a very highly positive and significant $(\mathrm{P}<0.001)$ correlation between milk energy and BF. Highly significant $(\mathrm{P}<0.01)$ negative correlation existed between milk protein and SNF $(r=-0.678 ; \mathrm{P}<0.01)$ while a highly significant $(\mathrm{P}<0.01)$ positive correlation existed between $\mathrm{BF}$ and milk protein $(r=0.730)$. Positive correlation coefficient indicates that the variables $(X$ and $Y)$ increased in the same direction while a negative correlation coefficient indicates that one variable (Y) decreased with increase in the other variable $(\mathrm{X})$.

Table 4. The relationship between milk yield and various constituents of WAD goat's milk from cassava peel cassava leaf meal based diets.

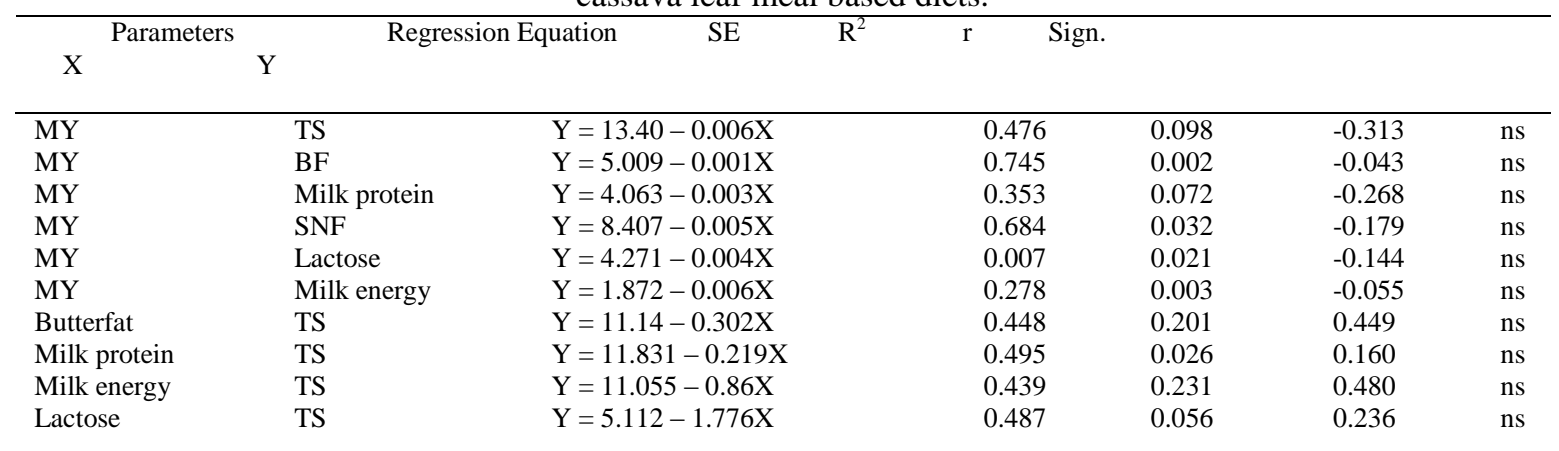


Evaluation Of Cassava Peel - Cassava Leaf Meal Based Diets For Milk Production By The ...

\begin{tabular}{llllll}
\hline Milk energy & BF & $\mathrm{Y}=0.0038-2.682 \mathrm{X}$ & 0.079 & 0.999 & 0.999 \\
& & & & \\
& & $\mathrm{Y}=12.334-1.287 \mathrm{X}$ & 0.511 & 0.460 & -0.678 \\
Milk protein & $\mathrm{SNF}$ & $\mathrm{Y}=4.368-0.804 \mathrm{X}$ & 0.693 & 0.006 & 0.077 \\
Lactose & $\mathrm{SNF}$ & $\mathrm{Y}=1.818-0.358 \mathrm{X}$ & 0.251 & 0.532 & 0.730 \\
BF & Milk protein & ns & $* *$ \\
\hline
\end{tabular}

Where MY $=$ Milk yield, $\mathrm{TS}=$ Total solids, $\mathrm{BF}=$ Butterfat, $\mathrm{SNF}=$ Solids - not - fat

$* *=\mathrm{P}<0.01$

$* * *=\mathrm{P}<0.001$

$\mathrm{ns}=$ Not significant

\section{Conclusion and Recommendation}

Milk yield and composition were improved by feeding cassava peel - cassava leaf meal based diets to lactating does. Diet D (30\% CLM) promoted a non - significant higher milk yield with low butterfat and high milk protein. These special attributes are highly essential for the obese, diabetic, hypertensive and aged patients (Okonkwo, 2001).

Animal protein intake in Nigeria can be improved by the incorporation of cassava leaf meal in concentrate diet for WAD goats. WAD goat is not essentially a dairy breed but its dairy potentials can be maximized through proper nutrition.

\section{References}

[1]. Ahamefule, F. O., Ibewuchi, J. A. and Ejiofor, C. A. (2003). A comparative study of the constituents of cattle, sheep and goat milk in a hot humid environment. Discov. and Innov. 15(1/2): $64-69$.

[2]. Ahamefule, F. O., Ibeawuchi, J. A. and Okonkwo, C. I. (2004). Comparative evaluation of the constituents of colostrums and milk of the WAD sheep and goat reared in a humid tropical environment. Nig. Agric. J., 35: $118-126$.

[3]. Ahamefule, F. O. (2005). Evaluation of pigeon pea - cassava peel based diets for goat production in South Eastern Nigeria. PhD thesis. Michael Okpara University of Agriculture, Umudike, Nigeria.

[4]. Ahamefule, F. O., Odilinye, O. and Nwachukwu, E. N. (2012). Milk yield and composition of Red Sokoto and West African Dwarf does raised intensively in a hot humid environment. Iranian Journal of Applied Animal Science. 2(2): 143 - 149.

[5]. Akpa, G. N., Asiribot, O. O. and Alawa, J. P. (2001). The influence of non - genetic factors on the shape of lactose curves in Red Sokoto goats. Anim. Sci., 72: 233 - 239.

[6]. Amaefule, K. U. (2002). Evaluation of pigeon pea seeds (C. cajan) as protein source for pullets. Ph.D. Thesis. Dept. of Animal Science, University of Nigeria, Nsukka.

[7]. Alikwe, P. C. N., Faremi, A. Y., Fajemisin, A. N. \& Akinsoyinu, A. O. (2011). Performances and nitrogen utilization of West African Dwarf goats fed soybean and dried poultry waste- based concentrates as supplements to cynodon nlemfuensis basal diet. Journal of Applied Sciences in Environmental Sanitation, 6 (2): 191 - 189.

[8]. Butswat, I. S. R., Zahraddeen, D., Mancha, Y. P. and Dachollom, C. C. (2002). Effects of breeds and parity on milk yield of Red Sokoto goats. Proceedings of the $7^{\text {th }}$ Annual Conference of Animal Science Association of Nigeria. September $16-19$, University of Agriculture, Abeokuta, Nigeria. Pp. $17-21$.

[9]. Duncan, D. B. (1955). Multiple range and Multiple F-test. Biometrics, 11: $1-42$.

[10]. F.A.O. (2005). Food and Agricultural Organization Annual report. 2005.

[11]. Ibeawuchi, J. A. (1987). Effects of feeding different levels of brewers' dried grain to lactating cows on yield and composition of milk. Bull Anim. Hlth. Prod. Afr., 35: 160 - 164.

[12]. Ibeawuchi, J. A. and Umoh, B. I. (1990). Constituents of milk of White Fulani (Zebu). Friesian and F1 Friesian X White Fulani cattle in a tropical environment. Bull. Anim. Hlth. Prod. Afr., 38: 253 - 257.

[13]. Ibeawuchi, J. A. and Dalyop, D. M. (1995). Composition and quality of fresh cow milk offered for sale in parts of Plateau State of Nigeria. Nig. J. Anim. Prod., 22(1): $81-84$.

[14]. Malau - Aduli, B. S., Eduvie, I. O., Lakpini, C. A. M. and Malau - Aduli, A. E. O. (2001). Effects of supplementation on the milk yield of Red Sokoto do. Proceedings of the $26^{\text {th }}$ Annual Conference of Nigerian Society for Animal Production, March 2001, ABU, Zaria, Nigeria, Pp. $353-355$.

[15]. Oboh, G. (2006). Nutrient enrichment of cassava peels using a mixed culture of Saccharomyces cerevisae and Lactobacillus spp. Solid media fermentation. Electronic Journal of Biotechnology, 9(1): 46 - 49.

[16]. Okonkwo, C. I. (2001). Comparative evaluation of the constituents of colostrums and milk of the West African Dwarf sheep and goats maintained in a humid tropical environment. B. Agric Thesis. Michael Okpara University of Agriculture, Umudike. Nigeria.

[17]. Ravindran, V. (1991). Preparation of cassava leaf products and their use as animal feed. In: Roots, tubers, plantains and bananas in animal feeding (Editors: DMachin and Solveig Nyvold). F. A. O Anim. Prod. And Hlth. Paper No: 95: 111 - 122.

[18]. Salami, R. I., Odunsi, A. A. (2003). Evaluation of processed cassava peels meals as substitutes for maize in the diets of layers. Int. J. Poult. Sci., 2(2): $112-116$.

[19]. Steele, R. G. C. and Torrie, S. H. (1980). Principles and Procedures of Statistics. McGraw Hill New York.

[20]. Ukanwoko, A. I. and Ibeawuchi, J. A. (2012). Carcass characteristics of West African Dwarf (WAD) goats fed cassava peel cassava leaf meal based diets. Bull. Env. Pharmacol. Life Scien. 1(11): 28 - 31.

[21]. Wanapat, M., Pimpa, O., Petlum, A. and Boontao, A. B. (1997). Cassava hay: A new strategic feed for ruminants during dry season. Livestock Res. for Rural Dev. 9(2) http://www.cipav.org.co/lrrd/lrrd9/2/metha92.htm

[22]. Zahraddeen, D., Butswat, I. S. R. and Mbap, S. T. (2007). Evaluation of some factors affecting milk composition of indigenous goats in Nigeria. Livestock Research for Kura Development. http://www.lrrd.org/lrrd19/11/zahr19166.htm 